\title{
Coefficient bounds for certain subclasses of bi-univalent functions
}

\section{ŞAHSENE ALTINKAYA and SiBEL YALÇIN}

\section{ABSTRACT.}

In this paper we discuss some newly constructed subclasses of bi-univalent functions and establish bounds for the coefficients of the functions in the subclasses $S_{\Sigma}(\lambda, \alpha)$ and $S_{\Sigma}(\lambda, \beta)$.

\section{REFERENCES}

[1] Altınkaya, Ş. and Yalçı, S., Initial coefficient bounds for a general class of bi-univalent functions, Int. J. Anal., 2014, Art. ID 867871, 4 pp.

[2] Altınkaya, Ş. and Yalçın, S., Coefficient Estimates for Two New Subclasses of Bi-univalent Functions with respect to Symmetric Points, J. Funct. Spaces, 2014, Art. ID 145242, 5 pp.

[3] Brannan, D. A. and Clunie, J., Aspects of contemporary complex analysis, Proceedings of the NATO Advanced Study Institute Held at University of Durham, New York: Academic Press, (1979)

[4] Brannan, D. A. and Taha, T. S., On some classes of bi-univalent functions, Studia Univ. Babes-Bolyai Math., 31 (1986), No. 2, 70-77

[5] Bulut, S., Faber polynomial coefficient estimates for a comprehensive subclass of analytic bi-univalent functions, C. R. Math. Acad. Sci. Paris Ser. I, 352 (2014), No. 6, 479-484

[6] Duren, P. L., Univalent Functions, Grundlehren der Mathematischen Wissenschaften, Springer, New York, 1983

[7] Frasin, B. A. and Aouf, M. K., New subclasses of bi-univalent functions, Appl. Math. Lett., 24 (2011) 1569-1573.

[8] Hamidi, S. G. and Jahangiri, J. M., Faber polynomial coefficient estimates for analytic bi-close-to-convex functions, C. R. Acad. Sci. Paris, Ser. I, 352 (2014), No. 1, 17-20

[9] Jahangiri, J. M. and Hamidi, G. S., Coefficient estimates for certain classes of bi-univalent functions, Int. J. Math. Math. Sci., 2013, Art. ID 190560, 4 pp.

[10] Lewin, M., On a coefficient problem for bi-univalent functions, Proc. Amer. Math. Soc., 18 (1967), 63-68

[11] Magesh, N. and Yamini, J., Coefficient bounds for a certain subclass of bi-univalent functions, Int. Math. Forum, 8 (2013), No. 27, 1337-1344

[12] Netanyahu, E., The minimal distance of the image boundary from the origin and the second coefficient of a univalent function in $|z|<1$, Arch. Ration. Mech. Anal., 32 (1969), 100-112

[13] Pommerenke, C., Univalent Functions, Vandenhoeck \& Ruprecht, Göttingen, 1975

[14] Srivastava, H. M., Mishra, A. K. and Gochhayat, P., Certain subclasses of analytic and bi-univalent functions, Appl. Math. Lett., 23 (2010), No. 10, 1188-1192

[15] Srivastava, H. M., Bulut, S., Çağlar, M. and Yağmur, N., Coefficient estimates for a general subclass of analytic and bi-univalent functions, Filomat 27 (2013), No. 5, 831-842

[16] Xu, Q. H., Gui, Y. C. and Srivastava, H. M., Coefficient estimates for a certain subclass of analytic and bi-univalent functions, Appl. Math. Lett., 25 (2012), 990-994

ULUDAG UNIVERSITY

DEPARTMENT OF MATHEMATICS

FACULTY OF ARTS AND SCIENCE

16059 BURSA,TURKEY

E-mail address: sahsene@uludag.edu.tr 